\title{
Exploring Gender-based Language Identity Among Iranian EFL Learners
}

\author{
Hossein Khodabakhshzadeh \\ English Department, Torbat-e Heydarieh Branch, Islamic Azad University, Torbat-e Heydarieh, Iran \\ E-mail: hkhodabakhshzade@gmail.com \\ Mansooreh Hosseinnia (Corresponding author) \\ English Department, Torbat-e Heydarieh Branch, Islamic Azad University, Torbat-e Heydarieh, Iran \\ E-mail: mansoorehhossinnia@yahoo.com \\ Fatemeh Ahmadi \\ English Department, Torbat-e Heydarieh Branch, Islamic Azad University, Torbat-e Heydarieh, Iran \\ E-mail: Fateme.ahmadi51@yahoo.com
}

Received: 20-11-2016

Accepted: 24-01-2017

Published: 01-07-2017 doi:10.7575/aiac.ijalel.v.6n.4p.70

Advance Access Published: April 2017

URL: http://dx.doi.org/10.7575/aiac.ijalel.v.6n.4p.70

\begin{abstract}
The purpose of this study is examining the language identity among male and female language learners in Iran. 1268 English language learners from different parts of the country from different ages and Iranian ethnicity and English language proficiency levels participated in this research. Validated and reliable scales of measuring language identity was used. The results of this study revealed that male and female English language learners are significantly different in their language identity and Iranian English language learners are in a moderate level of language identity. Moreover, the majority of the participants in each gender (male: $35.52 \%$, and female: $50.88 \%$ ) chosen American English as their favorite pronunciation kind, females (41.04) prefer Persian English more than males (20.94), and the lowest percent among male learners is related to Australian English (7.05) and among female learners is related to Canadian (1.54).
\end{abstract}

Keywords: Language identity; Male English language learners; Female English language learners; Iran

\section{Introduction}

"The language we use forms an important part of our sense of who we are - of our identity" (Edwards, 2009, p. 1). Khatib \& Rezaei (2013) understood "language as an identification badge provides one of the best telling clues for people's identity and where they belong to" (p.690).

Block (2007b), conceived language identity as the expected relationship between one's feeling of individual and a way of contact which might be recognized as a language, accent or a dialect (p. 40). Block (2013) added that we can look at identity with traditional demographic categories such as race, ethnicity, gender, social class, sexual, ethnolinguistic identity and national identity which we call them "identity inscriptions". Also, Block (2007) classified language identity into three main categories: L2 identity among the immigrants, L2 identity in second language context, and L2 identity in foreign language context.

Recently history in the social sciences is more about identity and its relationship with other variables such as ethnicity and community, and conflict and it has become the most important topics for investigation. (Dwivedi, 2015). The focus of this study is on gender differences in their L2 identity in foreign language context.

Bugarski (2012) in his study, make a distinction between linguistic identity and language identity, that linguistic identity refers to the language people use in a community with which they are associated, and the language identity refers to the identity of the language itself. In another study, Khatib \& Rezaei, \& Baleghizadeh (2014) carried out a nationwide survey of language identity among English language learners in Iran and indicated that there were significant differences in the language identity of participants across different age groups and language proficiency levels.

"With the rise of globalization and the importance of English as an international language, the majority of people in the whole world have felt the urge to learn English. This gradual but consistent desire to learn English has raised certain potential sociolinguistic and sociological concerns, one of which is pertinent to the identity of language learners after being exposed to English as a Foreign/Second language" (Khatib \& Rezaei, 2012, p.2). In Iran, the native language of people is Persian and with the rise of globalization and technology most people have preferred to learn English as their 
second language. So, by acquiring a second language, they are forming another identity in addition to their first language identity. In the area of language English identity, relatively few investigations have been administered in EFL contexts, especially in Iran. In this study, the major focus is given to the category of gender in language identity. Many studies have shown that males and females have much differences in their use of language. But, little studies have focused English language learners' identity including their gender identity. Therefore, the aim of this study is to investigate the difference between male and female Iranian language learners in their language identity.

\section{Literature Review}

\subsection{Language Identity}

Language can be one part of identity and vice versa. Norton (1997) believes that "the relationship between language and identity is an intriguing one, partly because debates on theories of language are as inconclusive and indeterminate as debates on theories of identity" (p. 409). According to Zou (2012), "English learners should enhance their cross-cultural communication skills. In order to achieve this goal, first of all, a thorough understanding of the relations between language, identity and cultural difference becomes necessary" (p.465).

West (1992) argues that identity refers to inclination to awareness, connection, and protection and safety.

According to Dwivedi (2015) "collective existence and experience of the people constitute identity" (p. 14). Also, Sen (2006) argues that a feeling of identity grant us dignity and reliance and strength. In Norton's (2011) word, identity is what some feminist post-structural theorists refer to as subjectivity. According to Block (2013) in the social sciences and applied linguistics "the default position as regards identity is to frame it as a social process as opposed to a determined and fixed product, following the tenets of what has come to be known as poststructuralism" (p. 17).

Recently, L2 educators are interested in the negotiation, construction and confliction of nature of identity (Norton, 1997). Bourdieu and Passeron (1977) in their study have had a sociocultural perspective on identity and language. In another study, Zou (2012) offered definitions of 'language', 'identity' and 'cultural difference 'and discussed the theory of Hall about the relation between those variables and provided an instance from his own living to show those relations

and finally, he evaluated the application of that theory to his individual experience.

Also, Khatib \& Rezaei, (2012) have done “a case study exploring an Iranian English language learner's identity within the Iranian EFL context and its potential relation with the success/failure and age of the learner" (p.1).

\subsection{Iranian identity}

"Iran is a country with diverse languages (multilingualism), ethnicities and cultures (multiculturalism), which makes it a good site for sociolinguistic research" (Khatib \& Rezaei, 2013, p.691). According to Beeman (2010) is the national and official language in Iran is Persian descending from the Indo-European languages also labelled as an Indo-Iranian language and it is spoken as the national language in Iran and in Afghanistan and Tajikistan. In the Iranian context, there are three types of cultural identity (Karimifard, 2012) which are 1. National Identity (the Pre-Islamic Iranian civilization), 2. Islamic Identity (the Post-Islamic Iran), and 3. the Modern or western Identity (the entry of modernity into Iran) (Pishghadam et al, 2015). Boroujerdi (1998) argued about two opposing points of view about Iranian identity: Iranian identity based on the religious view which is dominant in the Iran and secular view which is spread by the secular intellectuals. According to Yarshater (1993), the reason of survival of the Persian identity is only liking, acquiring, educating it, and upgrading this language.

\subsection{EFL Identity}

Pavlenco (2003 as cited in MostafaeiAlaei \& Ghamari, 2014) "argued that foreign-language learners may choose to reject the languages imposed on them, while others may instead reject the dominant national identity and create an alternative one through the means of a foreign language" (p.552). Talebi (2000) in his study indicated that there is no meaningful relation between level of study and mode of belonging to national identity. Also, in their study Lotfabadi and Nouroozi (2004) examined how Iranian high school students consider globalization and its influence on religious and national identities and values.

\section{Research Questions and Research Hypothesis}

This study aims to answer the following research questions:

RQ1. Are there any significant differences between male and female Iranian English language learners in their language identity?

RQ2. What is the degree of male and female Iranian English language learners' language identity measured through the language identity questionnaire?

RQ3. Are there any significant differences between male and female Iranian English language learners' preference on the use of American/ Canadian / British / Australian English, or Persian English?

Based on the research questions, the following null hypothesizes were formulated:

1. H0. There are any significant differences between male and female Iranian English language learners in their language identity.

2. H0. There are any significant differences between the degree of male and female Iranian English language learners' language identity. 
3. H0. There are any significant differences between male and female Iranian English language learners' preference on the use of American/ Canadian / British /Australian English, or Persian English.

In this study, language identity is distinguished by the manner individuals recognize each other by the language, dialect or accent they talk (Khatib \& Rezaei, 2014). In other words, in this study, language identity comprises six factors: pronunciation attitude, attachment to the Persian language, language and social status, language knowledge, L1 use/exposure in the society and script/alphabet which subsumed under the model in a survey instrument of Khatib and Rezaei (2013b).

\section{Methods}

\subsection{The Context and the Participants}

In this study, the participants are 1268 English language learners in Iran. With this aim, they were chosen based on stratified random and cluster sampling. The area/district (i.e. north, south, east, and west of Iran) were chosen as the strata; and the schools, institutes and universities were chosen as the cluster. The participants are different in their education degrees, age, sex, levels of language proficiency, schools and universities, and cities.

\subsection{Instrument}

Language Identity Questionnaire

This survey questionnaire was developed and validated by Khatib and Rezaei (2013b). It consisted of two parts. Part I, is related to personal characteristics of respondents, such as gender, English Language Proficiency Level, ethnicity and .... Part II has 19 items accompanied by a 6-point scale ranging from strongly agree to strongly disagree. The validation of the questionnaire have been done through exploratory and confirmatory factor analysis and its reliability was estimated to be 0.73 .

\subsection{Procedures}

This study aimed at investigating the difference between male and female Iranian language learners in their language identity.

The data collection done through Language Identity Questionnaire started in $5^{\text {th }}$ October, 2016 and ended in $22^{\text {th }}$ October.

The process of distribution of questionnaires was done by hand to hand method in schools, institutes, or colleges and via email. After gathering the data, they were calculated in SPSS software.

\subsection{Design of the Study}

The design of this study is experimental with stratified random and cluster sampling. It is implemented based on quantitative approach.

\section{Data Analyses}

In this study, an attempt was made to answer to the three research questions concerning the difference between male and female Iranian language learners in their language identity. Suitable statistical analyses were done to obtain the answer for those three questions. Also, descriptive statistics for the scale used in this study were reported. Following this, the results of mean and standard deviation and T-test are reported and discussed.

\subsection{Results and Discussion}

The reliability, or internal consistency, of the questionnaire was measured through Cronbach's alpha. Its reliability of the total questionnaire was estimated to be 0.71 .

\section{Research Question one}

RQ1. Are there any significant differences between male and female Iranian English language learners in their language identity?

To answer the first research question aiming at examining whether learners' language identity differs significantly between genders an independent-samples t-test was performed. Table 1 shows the descriptive statistics of males and females' scores in language identity. Results of the independent-samples t-test is presented in Table 2.

Table 1. The Descriptive Statistics of Males and Females' Scores in Language Identity

\begin{tabular}{lllll}
\hline & Gender & N & Mean & Std. Deviation \\
\hline \multirow{2}{*}{ Language Identity } & M & 424 & 69.6014 & 9.94662 \\
& F & 843 & 71.7687 & 10.04573 \\
\hline
\end{tabular}

As the table shows, the mean score of females (71.76) in language identity questionnaire is higher than males (69.60). To find that this difference is significant statistically, t-test was run (see table 2). 
Table 2. Results of the independent-samples t-test

\begin{tabular}{llllll}
\hline \multicolumn{7}{l}{$t$-test for Equality of Means } & & & \\
\hline & $\mathrm{t}$ & $\mathrm{df}$ & Sig. (2-tailed) & Mean & Std. Error \\
& & & & Difference & Difference \\
Language Identity & -3.636 & 1265 & .000 & -2.16727 & .59613 \\
\hline
\end{tabular}

Levene's test indicated homogeneity of variance on the language identity. As indicated in table 2, there is a significant difference between gender and language identity $(t=-3.636, p=.000)$. So, male and female English language learners are significantly different in their language identity in general.

The finding in this part can be compared with the results of the study of Khatib \& Rezaei (2014). They measured the language identity of English language learners in general. They concluded that English language learners in Iran have moderate language identity. Also, in one part, their findings showed that there are no significant differences between language identity of men and women English learners. Therefore, the findings of this study are contradictory with their findings.

Also, in another study with the title of "language policy and language awareness" done by Davari-Ardakani (2006), his results have been shown that there were no significant relationships among gender, mother tongue, birthplace, stay abroad more than six month, knowing multiple languages, attitude to the Persian language, and length of residence in Tehran.

\section{Research Question two}

RQ2.What is the degree of male and female Iranian English language learners' language identity measured through the language identity questionnaire?

In order to answer the second research question, the learners' language identity scores were categorized to the low, moderate and high groups. To do so, the mean and standard deviation were computed. The scores falling one standard deviation above and below the mean were considered as the high and low scores, respectively. And finally, the scores between these two belonged to the moderate zone. The results of the questionnaire administration to 1268 Iranian English language learners across the country indicated that the mean score and the standard deviation obtained were 71.04 and 10.06, respectively.

Subsequently, the scores between 38.9 and 70.5 were considered to be moderate and the scores below 60.98 and above 81.10 showed low and high language identity, respectively. To interpret the scores obtained from the questionnaire, the higher the scores were, the more the participants felt attached to their first language, i.e. in this study Persian language identity.

The results of the survey showed Iranian learners exhibited a moderate level of language identity. More specifically, of all the participants in this study, $14.4 \%$ belonged to the high language identity group and $12.9 \%$ and $72.7 \%$ belonged to the low and moderate language identity groups, respectively.

So, as I mentioned above, Khatib \& Rezaei (2014) concluded that English language learners in Iran have moderate language identity. Therefore, the result of this part is similar to their result. In other words, based on these two studies, Iranian learners have been proven that have a moderate level of language identity.

Also, Davari-Ardakani and Mostafa's (2011) in their study which has been done among the Kurd participants of their study showed that the Kurd people have mostly an average attitude toward Persian.

\section{Research Question three}

RQ3. What variety of English do Iranian English language learners prefer more in each gender: American/British/Canadian/Australian English, or Persian English?

In order to find out which type of variety of English was used more by Iranian learners, the frequency and percent were computed. Table 3 shows frequency and percent of each option among Iranian male and female English learners.

Table 3. Frequency and Percent of Each Option among Iranian Male and Female English Learners

\begin{tabular}{|c|c|c|c|c|c|c|}
\hline & \multicolumn{2}{|l|}{ Total } & \multicolumn{2}{|l|}{ Male } & \multicolumn{2}{|l|}{ Female } \\
\hline & Frequency & Percent & Frequency & Percent & Frequency & Percent \\
\hline British & 126 & 10 & 92 & 21.64 & 34 & 4.03 \\
\hline American & 580 & 45.7 & 151 & 35.52 & 429 & 50.88 \\
\hline Canadian & 76 & 6.0 & 63 & 14.82 & 13 & 1.54 \\
\hline Australian & 51 & 4.0 & 30 & 7.05 & 21 & 2.49 \\
\hline Persian & 435 & 34.3 & 89 & 20.94 & 346 & 41.04 \\
\hline Total & 1268 & 100.0 & 425 & 100 & 843 & 100 \\
\hline
\end{tabular}


As the results showed, the majority of the participants in each gender (male: $35.52 \%$, and female: $50.88 \%$ ) selected American English as their favorite pronunciation type. In addition, the results indicated that females (41.04) prefer Persian English more than males (20.94). Moreover, the lowest percent among male learners is related to Australian English (7.05) and among female learners is related to Canadian (1.54). So, more females prefer American English than males and lower females prefer Canadian English and lower males prefer Australian English pronunciation.

In the case of Khatib \& Rezaei's (2014) study, like this study the majority of the participants selected American English as their favorite pronunciation type. In their study, 73.3\% selected American English, but in this study, 47\%. Also, in both studies, the lowest percent among learners is related to Australian English and Canadian (1.54). In this regard, Khatib \& Rezaei's (2014) argued that "the reasons why Australian and Canadian Englishes were not as favorable as Persian English could be related to their being less known in the Iranian context; however, this should not make these two varieties of English as non-acceptable in Iran" (p. 7). Also, the American films and TV series are more accessible for Iranians than the films with the pronunciation of Australian and Canadian. Chaichian (1997) investigated identity in diaspora among Iranian immigrants in Iowa and the findings of our study also confirm the findings of Chaichian's study in that English language learners in Iran still have a strong feeling of connection to their language, as Chaichian found in Iowa. Also, among studies have been done in Iranian context, Modarresi (2001) studied the sociolinguistics of Persian and identity in diaspora. In this perspective, Borjian (2013) investigated English in post-revolutionary Iran and Jamarani (2012a,2012b) considered Iranian women gender identity in diaspora. Moreover, Schumann (cited in Hoffman 1989) described her own experience in Iran and how Iranians tried to speak English before the 1979 Revolution to manifest a high prestige even among their own Persian friends.

\section{Conclusion}

Identity has been one of the most concerns of language teachers and researchers. In this study the factor of gender has been considered in language identity. In other words, this study has been done with the aim of distinguishing the language identity in male and female language learners in Iran context. According to the result, male and female English language learners are significantly different in their language identity. This result can be because of the differences existed in the kind of attitude in males and females or some other factors. Also, this study has been shown that Iranian learners exhibited a moderate level of language identity. In addition, the majority of the participants in each gender (more by female) selected American English as their favorite pronunciation type. So, we have investigated the gender in language identity in detail.

Results of this study provide teachers and practitioners useful implications. It was indicated the attitudes and the level of identity which Iranian English learners have toward language and the kind of identity between males and females. It was also showed the relations of identity of two languages and their influences on each other. Furthermore, it was showed the situation of Persian and English in Iran and between language learners. In addition, it was indicated that males and females can be also different in their language identity.

Other researchers also have investigated language identity in different dimensions with different tools and methodologies. Norton (2013) in his study if English learners have sense of possession over meaning-making, they will have improved their identities as take part more actively in literacy activities. In another study, Jing \& Jianbin (2007) investigated the relationship between identity and language learning in China. They argued that language learning in China context is different from in English speaking countries and in order to promote the learners' identity, the teachers should induce and motivate learners. Pavlenko and Norton (2007) in their investigation presented the concept of "imagined communities" to show the relationship between second language learning and identity and discussed that language learners' membership in "imagined communities" can affect in improving their learning and identity.

This study has its own limitations. For example, level of English learners' identity was calculated with just a questionnaire. Other studies are needed to be implemented by other instruments such as interview and etc. Also, other studies can be considered the relationship between language identity and other variables.

\section{Acknowledgements}

We really appreciate the ones who have helped us in the process of preparation and collection of this paper.

\section{References}

Beeman, W. O. (2010). Sociolinguistics in the Iranian World. In The Routledge Handbook of Sociolinguistics in the World, edited by M. J. Ball, 139_148. London: Routledge.

Block, D. (2013). Issues in language and identity research in Applied Linguistics. ELIA, 13, 11-46. DOI: http://dx.doi.org/10.12795/elia.2013.i13.01

Borjian, M. 2013. English in Post-Revolutionary Iran: From Indigenization to Internationalization. Bristol: Multilingual Matters.

Bourdieu, P., \& Passeron, J. S. (1977). Reproduction in education, society, and culture.Beverly Hills, CA: Sage.

Boroujerdi, M. (1998). Contesting Nationalist Constructions of Iranian Identity. Critique 12: $43-55$. doi:10.1080/10669929808720120. 
Bugarski, R. (2012). Language, Identity and Borders in the Former Serbo-Croatian Area. Journal of Multilingual and Multicultural Development 33(3), 219-235. doi:10.1080/01434632.2012.663376.

Chaichian, M. A. (1997). First Generation Iranian Immigrants and the Question of Cultural Identity: The Case of Iowa. International Migration Review, 31(3), 612-627. doi:10.2307/2547288.

Davari-Ardakani, N. (2006). "Barnāmah-rizi zabān va hūšyāri zabāni: Bā negāhi be Iran." [Language Policy and Language Awareness: A Look on Iran]. PhD diss., University of Tehran.

Davari-Ardakani, N., \& T. Mostafa. (2011). Barresi-e negareš-hāye zabāni va jāygāh-e do zabān- e Fārsi va Kurdi dar hoviat-e meli. [Investigating Language Attitudes and the Place of Persian and Kurdish Language in National Identity]. Iran Nameh 26(1, 2): 209-222.

Dwivedi, A. V. (2015). Language, Identity, and Gender: A Study of Creole in the Caribbean. Linguistics and Literature Studies, 3(1): 11-17. DOI: 10.13189/lls.2015.030102

Edwards, J. (2009). Language and Identity: An Introduction. New York, NY: Cambridge University Press.

Hoffman, D. M. (1989). "Language and Culture Acquisition among Iranians in the United States." Anthropology \& Education Quarterly, 20(2): 118-132. doi:10.1525/aeq.1989.20.2.05x0843k.

Jamarani, M. (2012a). "Encountering Differences: Iranian Immigrant Women in Australia." In Feminism and Migration: Cross-cultural Engagements, edited by G. T. Bonifacio, 149-164. Dordrecht: Springer.

Jamarani, M. (2012b). Identity, Language, and Culture in Diaspora: A Study of Iranian Female Migrants to Australia. Melbourne: Monash University.

Jing, L. \& Jianbin, H. (2007). Reflections on identity and English language teaching in China. Polyglossia, 13, 53-57

Karimifard, H. (2012). Constructivism, national identity and foreign policy of the Islamic Republic of Iran. Asian Social Science,8(2), 239-246.

Khatib, M. \& Rezaei, S. (2012). The portrait of an Iranian as an English Language Learner: A case of identity reconstruction. International Journal of Research Studies in Language Learning, 1(1), 1-14.

Khatib, M. \& Rezaei, S. (2013). A model and questionnaire of language identity in Iran: a structural equation modelling approach. Journal of Multilingual and Multicultural Development, 34(7), 690-708.

Khatib, M. \& Rezaei, S. \& Baleghizadeh, S. (2014). Language identity among Iranian English language learners: a nationwide survey. Journal of Multilingual and Multicultural Development, 5(35), 1-10.

Lotfabadi, H. and Nouroozi, V. (2004). Barrasi-e-chegoonegi-e-negaresh-e-daneshamoozandabirestanivapishdaneshgahi-e- iran bejahanishodan....., How Iranian high school students think about Globalization and its effect on religious and national identity. Journal of Educational Innovations, 9, pp. 88-119.

Modarresi, Y. 2001. "The Iranian Community in the United States and the Maintenance of Persian." International Journal of the Sociology of Language, 148, 93-116. doi:10.1515/ijs1.2001.017.

MostafaeiAlaei, M. \& Ghamari, M. R. (2014). The Movement of EFL learning approaches toward identity constructs: A gradual development or a social turn. European Online Journal of Natural and Social Sciences, 3(3), 549-563.

Norton, B. (1997). Language, identity, and the ownership of English. TESOL Quarterly, 31(3), 409-429.

Norton, B. (2011). Identity. In J. Simpson (ed.), The Routledge handbook of applied linguistics (pp. 318-330). London and New York: Routledge.

Norton, B. (2013). Identity, literacy, and English language teaching. Iranian Journal of Language Teaching Research 1(2), 85-98.

Pavlenko, A. (2003). 'Language of the enemy': Foreign language education and national identity. International Journal of Bilingual Education and Bilingualism, 5(6), 313-331.

Pavlenko, N. \& Norton, B. (2007). Imagined Communities, Identity, and English Language Learning. International Handbook of English Language Teaching, 15 ,589-600

Pishghadam, R. \& Saboori, F. \& Hosseini Fatemi, A. Ghonsooli, B. (2015). Culture and identity: Linking Iranian identity components and cultural dimensions. Issues in Language Teaching (ILT), 1(4), 49-78.

Rezaei, S. (2012). Researching identity in applied linguistics. The International Journal - Language Society and Culture, $35,45-51$.

Sen, A. (2006). Identity and Violence: The Illusion of Destiny. New York: W.W. Norton \& Co; pp.2-3.

Talebi, S. (2000).Tahavvol-e- hoviiat-e- daneshamoozan-e- shahr-e- Tehran, Change of national identity among primary to high school Girl students in Tehran, Unpublished M. A. thesis, Modarres Teacher Training University.

West, C. (1992). A matter of life and death. October, 61, 20-23.

Yarshater, E. (1993). Persian Identity in Historical Perspective. Iranian Studies 26 (1_2), 141-42. doi:10.1080/00210869308701791

Zou, H. (2012). Language identity and cultural difference. International Journal of Social Science and Humanity, 6(2), 465-467. 